\title{
Protection against Staphylococcus aureus and tetanus infections by a combined vaccine containing SasA and TeNT-Hc in mice
}

\author{
YILONG YANG* ${ }^{*}$ RUI YU* ${ }^{*}$ XIUXU YANG, SHULING LIU, TING FANG, XIAOHONG SONG, \\ LIHUA HOU, CHANGMING YU, JUNJIE XU, LING FU, SHAOQIONG YI and WEI CHEN
}

\begin{abstract}
Laboratory of Vaccine and Antibody Engineering, Beijing Institute of Biotechnology, Fengtai, Beijing 100071, P.R. China
\end{abstract}
Received December 11, 2015; Accepted December 19, 2016

DOI: $10.3892 / \mathrm{mmr} .2017 .6227$

\begin{abstract}
In developing countries, trauma patients and neonates are vulnerable to Staphylococcus aureus (S. aureus) and Clostridium tetani infections. It has been suggested that a combined vaccine against the two infections may be a reliable and cost-effective strategy. Previous studies have indicated that the S. aureus surface protein A (SasA) and the C fragment of tetanus neurotoxin (TeNT-Hc) may be suitable candidates for a vaccine against $S$. aureus and tetanus infections, respectively. In the present study, mice were immunized with a combined vaccine containing SasA and TeNT-Hc, which induced a robust immune response to both antigens, and mutual interference between SasA and TeNT-Hc was not observed. In the S.aureus challenge model, the combined vaccine fully protected BALB/c mice against lethal intraperitoneal challenges with $3 \times 10^{9}$ colony-forming units of a methicillin-resistant $S$. aureus USA300 strain. In the TeNT challenge model, the combined vaccine conferred complete protection against a lethal dose of $\left(2 \times 10^{3}\right) \times L D 50$ tetanus toxin. These results implied that SasA and TeNT-Hc promising components for a combined vaccine against $S$. aureus and tetanus infections.
\end{abstract}

Correspondence to: Professor Wei Chen or Dr Shaoquiong Yi, Laboratory of Vaccine and Antibody Engineering, Beijing Institute of Biotechnology, 20 Dongdajie Street, Fengtai, Beijing 100071, P.R. China

E-mail: cw0226@foxmail.com

E-mail: yishaoqiong@126.com

*Contributed equally

Abbreviations: S. aureus, Staphylococcus aureus; MRSA, Methicillin-resistant $S$. aureus; IsdB, iron-responsive surface determinant B; TeNT-Hc, C fragment of tetanus neurotoxin; SasA, Staphylococcus aureus surface protein A; ELISA, enzyme-linked immunosorbent assay; TMB, 3,3',5,5'-tetramethylbenzidine dihydrochloride

Key words: vaccine, Staphylococcus aureus, tetanus neurotoxin, protective immunity trauma

\section{Introduction}

Clinical trauma patients are frequently diagnosed with Staphylococcus aureus (S. aureus) and tetanus infections, particularly those in developing countries $(1,2)$. These infections have contributed greatly to the morbidity and mortality rates of neonates in developing countries such as Nigeria (3). S. aureus colonizes in approximately one-third of the human population (4), and is responsible for various diseases ranging from skin and soft tissue infections to life-threatening septicemia with metastatic complications (5). Tetanus is caused by tetanospasmin, a neurotoxin produced by the obligate anaerobic bacterium Clostridium tetani. Although the incidence of tetanus is low in developed countries, the worldwide mortality rates range from $6-72 \%$ (6), depending on the medical condition. In 2013, the World Health Organization estimated that $\sim 49,000$ newborns died from neonatal tetanus (7).

Combination vaccines are a reliable strategy to protect against two or more pathogens, and may reduce costs of mass vaccination and disposables (8). Those susceptible to trauma, including athletes, soldiers and the police, as well as women of childbearing age in developing countries, may benefit from the development of a combined vaccine against S. aureus and tetanus infections. S. aureus surface protein A (SasA), a cell wall-anchored protein of $S$. aureus, consisting of 2,271 amino acid residues, is a potential vaccine candidate for $S$. aureus infections (9). SasA has been reported to be a virulence determinant in endovascular infections, as the SasA mutant strain was observed to decrease the ability of catheterized rabbits to form vegetative plaques on heart valves (10). In addition, SasA is prevalent in $S$. aureus clinical isolates, and is expressed during in vivo growth of the bacteria (11). Notably, immunization with SasA was able to protect mice against a lethal S. aureus challenge (9). The tetanus toxin is a $150 \mathrm{kDa}$ protein that has three domains (12), including the $\mathrm{N}$-terminal zinc endopeptidase domain (13), the internal heavy chain translocation domain and the $\mathrm{C}$-terminal heavy chain receptor-binding domain known as the $\mathrm{C}$-fragment of tetanus neurotoxin (TeNT-Hc) (14). The genetic recombinant TeNT-Hc, which is nontoxic but has ganglioside binding activities, has been proposed as a possible replacement for the tetanus toxoid vaccine (15). TeNT-Hc is expected to demonstrate clear advantages over the existing tetanus toxoid vaccine with regard to ease of production, homogeneity and characterization. 
In the present study, mice were immunized with a combined vaccine consisting of SasA (9) and TeNT-Hc (16) formulated by adsorption to Alhydrogel. The antibody titers and protective efficacy were measured for individual and combined vaccine administrations. The results demonstrated that the combined vaccine was able to induce protective immunity against $S$. aureus and tetanus neurotoxin challenges.

\section{Materials and methods}

Bacterial strains and growth conditions. The $S$. aureus strain USA300 (BAA-1556 ${ }^{\mathrm{TM}}$; American Type Culture Collection, Manassas, VA, USA) was cultivated in tryptic soy broth (TSB; tryptone $15 \mathrm{~g} / 1$, soybean peptone $5 \mathrm{~g} / 1, \mathrm{NaCl} 5 \mathrm{~g} / 1$, pH 7.2, used after $\left.121^{\circ} \mathrm{C}, 20 \mathrm{~min}\right)$ at $37^{\circ} \mathrm{C}$. The Escherichia coli (E. coli) strain BL21 (DE3; Merck Millipore, Darmstadt, Germany) were cultivated in Luria-Bertani broth (tryptone $10 \mathrm{~g} / \mathrm{l}$, yeast extract $5 \mathrm{~g} / \mathrm{l}, \mathrm{NaCl} 10 \mathrm{~g} / \mathrm{l}, \mathrm{pH} 7.2$, used after $121^{\circ} \mathrm{C}, 20 \mathrm{~min}$ ) at $37^{\circ} \mathrm{C}$ and $100 \mu \mathrm{g} / \mathrm{ml}$ ampicillin (10 g ampicillin powder dissolved in $100 \mathrm{ml} \mathrm{H}_{2} \mathrm{O}$, used after filtration and diluted 1:1,000) was used for plasmid selection.

Subunit antigens. The antigens used in the current study were expressed in E. coli BL21 (DE3) and purified to $>90 \%$. The purification protocols were the same as described previously $(9,16)$. Briefly, the polyhistidine-tagged recombinant SasA (rSasA) was purified by anion exchange, HisTrap and gel filtered chromatography (GE Healthcare Bio-Sciences, Pittsburgh, PA, USA). The non-tagged TeNT-Hc antigen was purified by anion exchange, hydrophobic interactions and gel-filtered chromatography (GE Healthcare Bio-Sciences).

Active immunization. A total of 40 female BALB/c mice (age, 6-8 weeks; weight, 18-20 g) were purchased from The Beijing Laboratory Animal Center (Beijing, China), and were divided into 4 groups of 10 mice each. All mice had free access to food/water and were raised under standard conditions (temperature $25 \pm 2^{\circ} \mathrm{C}$, relative humidity $50 \pm 10 \%$ ) with a dark/light cycle $(14 / 10 \mathrm{~h})$. The mice were immunized intraperitoneally with $10 \mu \mathrm{g}$ rSasA, $10 \mu \mathrm{g}$ TeNT-Hc, $10 \mu \mathrm{g}$ rSasA $+10 \mu \mathrm{g}$ TeNT-Hc adsorbed to $0.75 \mathrm{mg}$ aluminum hydroxide adjuvant (Brenntag Biosector A/S, Frederikssund, Denmark). The $0.75 \mathrm{mg}$ aluminum hydroxide adjuvant was used as a negative control. Mice were injected at weeks 0, 2 and 4. Blood samples were drawn at weeks 2, 4 and 6 and every 4 weeks thereafter until week 26 through the tail vein and screened for reactivity to rSasA or TeNT-Hc antigens. Subsequent to the experiments, all mice were sacrificed by $\mathrm{CO}_{2}$ asphyxiation. All experiments were performed in agreement with the institutional guidelines approved by the Laboratory Animal Care and Use Committee of the Beijing Institute of Biotechnology (IACUC of AMMS-08-2014-006).

Serological analysis of antibodies. Serum antibody titers of the antigen-specific total IgG, IgG1 and IgG2a were determined by enzyme-linked immunosorbent assay (ELISA). Microplates (96-well) were coated overnight with rSasA or TeNT-Hc $(2 \mu \mathrm{g} / \mathrm{ml})$ in coating buffer $(50 \mathrm{mM}$ carbonate buffer, $\mathrm{pH} 9.6)$ at $4^{\circ} \mathrm{C}$. The plates were blocked with $2 \%(\mathrm{w} / \mathrm{v})$ bovine serum albumin (2 g dissolved in $100 \mathrm{ml} \mathrm{H}_{2} \mathrm{O}$; Sigma-Aldrich; Merck
Millipore) in PBS at $37^{\circ} \mathrm{C}$ for $1 \mathrm{~h}$. Duplicate two-fold serial dilutions of serum in an appropriate range $(1: 100 \sim 1: 409,600)$ were incubated in the plates at $37^{\circ} \mathrm{C}$ for $1 \mathrm{~h}$ followed by washing with PBS with $3 \%$ Tween 20 (PBST). Then horseradish peroxidase-labelled goat anti-mouse total $\mathrm{IgG}, \mathrm{IgG} 1$ (ab97240; 1:10,000) or IgG2a (ab97245; 1:10,000) antibodies (Abcam, Cambridge, MA, USA) were applied for $1 \mathrm{~h}$ at $37^{\circ} \mathrm{C}$ and then washed with PBST. The plates were incubated with 3,3',5,5'-tetramethylbenzidine dihydrochloride substrate (Sigma-Aldrich; Merck Millipore) at room temperature for $10 \mathrm{~min}$ in the dark. The colorimetric reaction was stopped with $2 \mathrm{M}$ sulfuric acid, and the optical density at $450 \mathrm{~nm}\left(\mathrm{OD}_{450}\right)$ was read in a microplate reader (Bio-Rad Laboratories, Inc., Hercules, CA, USA). Each step was followed by washing three times with PBST. The antibody-positive cut-off values were set as two times greater than the $\mathrm{OD}_{450}$ means of the pre-immunized sera. The ELISA antibody titer was expressed as the highest serum dilution showing a positive reaction.

S. aureus challenge model. Overnight cultures of $S$. aureus strain USA300 were diluted 1:100 in fresh TSB and cultivated at $37^{\circ} \mathrm{C}$ until reaching the mid-late logarithmic phase. S. aureus challenge was performed as described previously (17). Immunized mice were challenged by intraperitoneal injection with a lethal dose of $S$. aureus USA300 ( $3 \times 10^{9}$ colony-forming units in $100 \mu \mathrm{l} /$ mouse), at 6 weeks after the primary immunization. Infected animals were monitored for survival for 5 days.

TeNT challenge model. At 6 weeks following primary immunization, the mice were challenged with $\left(2 \times 10^{3}\right) \times L D 50$ s (the LD50 in mice was determined by the improved Karber method (18). The LD50 of tetanus neurotoxin was $\sim 15.8 \mathrm{ng} / \mathrm{kg}$ in mice) of tetanus neurotoxin [in $0.5 \mathrm{ml}$ borate-buffered saline ( $0.5 \mathrm{~g}$ borax, $4.5 \mathrm{~g}$ boric acid and $8.5 \mathrm{~g}$ sodium chloride in 11 distilled water)] by subcutaneous injection. Survival was monitored for five days.

Statistical analysis. Unpaired Student's two-tailed $t$-test was used to analyze the differences in ELISA titers between the groups. To compare the survival rates in the challenge models, experiments were analyzed using the Gehan-Breslow-Wilcoxon test with GraphPad Prism 5.01 (GraphPad Software, Inc., La Jolla, CA, USA). P $\leq 0.05$ was considered to indicate a statistically significant difference.

\section{Results}

Antibody titer following immunization. A total of 3 groups of 10 mice were intraperitoneally immunized three times (at weeks 0, 2 and 4) with $10 \mu \mathrm{g}$ rSasA, $10 \mu \mathrm{g}$ TeNT-Hc or $10 \mu \mathrm{g}$ rSasA $+10 \mu \mathrm{g}$ TeNT-Hc. Blood samples were collected periodically through the tail vein to assay antigen-specific antibody responses by ELISA. The responses were compared between the groups over 26 weeks (Fig. 1). Detectable levels of IgG against rSasA and TeNT-Hc antigens were observed at 2 weeks following primary immunization, and the titers were maintained over 6 months.

No significant differences in TeNT-Hc specific IgG titers were observed between the TeNT-Hc immunized group and TeNT-Hc + SasA immunized group over the 

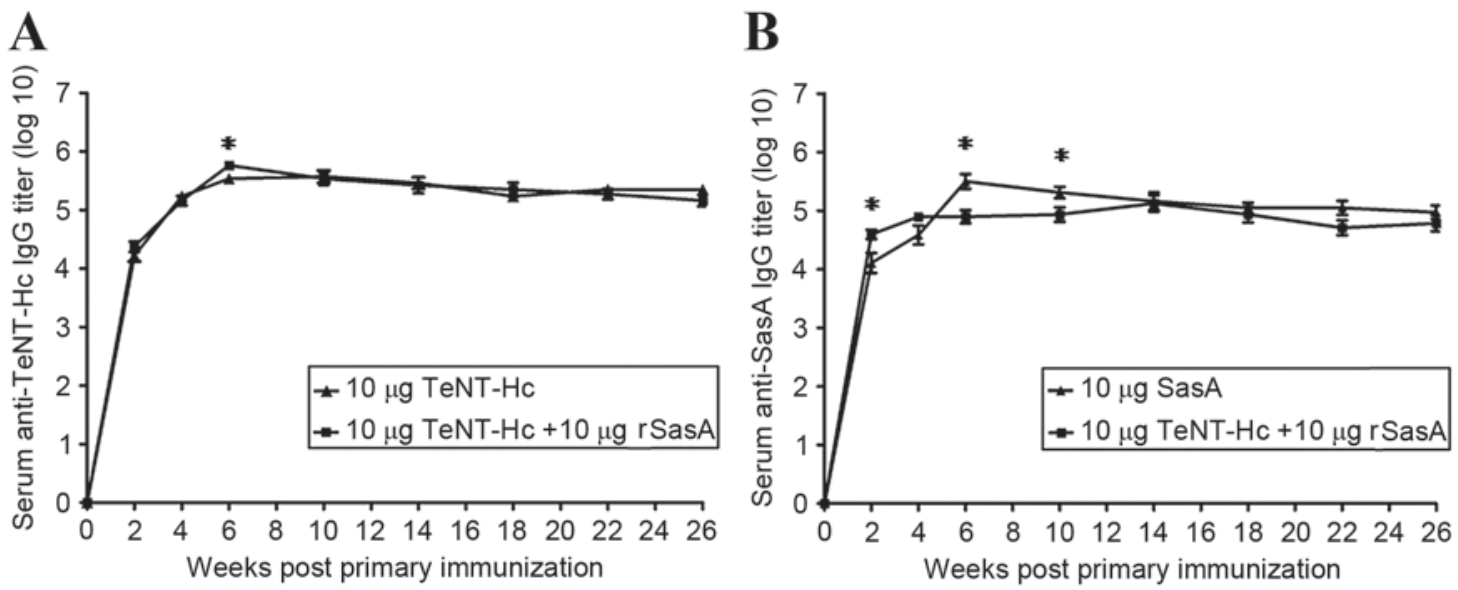

Figure 1. Kinetics of the $\mathrm{IgG}$ response in BALB/c mice following vaccination. A total of 3 groups of 10 mice were immunized three times (at weeks 0,2 and 4 ) intraperitoneally with $10 \mu \mathrm{g}$ rSasA, $10 \mu \mathrm{g}$ TeNT-Hc or $10 \mu \mathrm{g}$ rSasA $+10 \mu \mathrm{g}$ TeNT-Hc. Serum of immunized mice were collected to monitor antigen-specific IgG response by ELISA; (A) Serum anti-TeNT-Hc IgG and (B) serum anti-SasA IgG titers. Data are presented as the $\log 10$ mean antibody titers for each group. The error bars represent the significant error. Unpaired two-sided Student's $t$-test was employed to assess the significant difference between groups. " $\mathrm{P}<0.05$ vs. $10 \mathrm{mg}$ TeNT-Hc + 10 SasA. IgG, immunoglobulin G; rSasA, recombinant Staphylococcus aureus surface protein; TeNT-Hc, C fragment of tetanus neurotoxin; ELISA, enzyme-linked immunosorbent assay.

26 weeks (Fig. 1A), except for the week 6, when the combined vaccine induced anti-TeNT-Hc IgG titers 1.683-fold higher than TeNT-Hc ( $\mathrm{P}=0.0313)$. Significant differences in rSasA specific IgG titers were observed between the rSasA immunized group and the TeNT-Hc + SasA immunized group in weeks 2, 6 and 10 (Fig. 1B). The combined vaccine induced rSasA specific IgG titers 3.083-fold higher than rSasA alone at week $2(\mathrm{P}=0.0210)$. However, at weeks 6 and 10 , the combined vaccine induced $\mathrm{rSasA}$ specific $\operatorname{IgG}$ titers 3.999 times $(\mathrm{P}=0.0032)$ and 2.377 times $(\mathrm{P}=0.0323)$ lower than rSasA alone, respectively.

$\operatorname{Ig} G$ isotyping. Serum samples from immunized mice at week 6 were assayed for the presence of antigen-specific IgG1 and $\operatorname{IgG} 2 \mathrm{a}$ antibodies by ELISA. rSasA and the combined vaccine induced the robust production of $\operatorname{IgG} 1$ and $\mathrm{IgG} 2 \mathrm{a}$ antibodies specific to rSasA (Fig. 2). No significant differences in rSasA IgG1 and IgG2a titers were observed between the rSasA and rSasA + TeNT-Hc groups. Similar results were observed from TeNT-Hc-immunized mice and the combined vaccine-immunized mice (Fig. 2). The combined vaccine induced specific IgG1 and IgG2a titers comparable to rSasA or TeNT-Hc vaccines. Additionally, the antigen-specific $\mathrm{IgG} 1 / \operatorname{IgG} 2 \mathrm{a}$ ratio was not influenced by co-administration of the two antigens (data not shown).

In vivo protection against $S$. aureus challenge. Immunized mice were challenged by intraperitoneal inoculation with $3 \times 10^{9}$ colony-forming units of $S$. aureus USA300, 6 weeks following primary immunization. Approximately $90 \%$ of mice in the control group died within $24 \mathrm{~h}$ (Fig. 3A). By contrast, immunized mice survived for $120 \mathrm{~h}$ post challenge. All mice immunized with $10 \mu \mathrm{g}$ rSasA or $10 \mu \mathrm{g} \mathrm{rSasA}+10 \mu \mathrm{g}$ TeNT-HC survived the challenge with symptoms of infection such as temporary leg paralysis.

In vivo protection against tetanus neurotoxin. The mice vaccinated three times with $10 \mu \mathrm{g}$ TeNT-Hc or $10 \mu \mathrm{g}$ rSasA $+10 \mu \mathrm{g}$

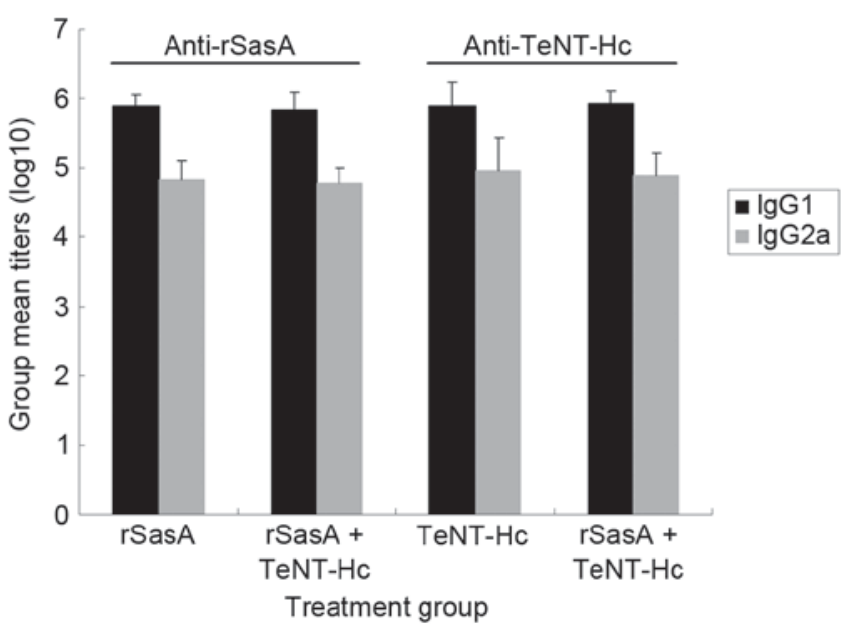

Figure 2. Antigen-specific IgG1 and IgG2a antibody titers induced by rSasA, TeNT-Hc and the combined vaccine. A total of 3 groups of 10 mice were immunized three times (at weeks 0,2 and 4) intraperitoneally with $10 \mu \mathrm{g}$ rSasA, $10 \mu \mathrm{g}$ TeNT-Hc or $10 \mu \mathrm{g}$ rSasA+10 $\mu \mathrm{g}$ TeNT-Hc. Serum of immunized mice were collected at 6 weeks following primary immunization. The antigen-specific IgG1 and IgG2a responses were determined by ELISA. No significant differences were observed. Data are presented as the $\log 10$ of the mean antibody titers for each group. The error bars represent the standard error. Unpaired two-sided Student's $t$-test was employed to assess the significant difference between groups. IgG, immunoglobulin G; rSasA, recombinant Staphylococcus aureus surface protein; TeNT-Hc, C fragment of tetanus neurotoxin; ELISA, enzyme-linked immunosorbent assay.

TeNT-Hc were challenged with tetanus neurotoxin, and its protective abilities were evaluated. When challenged with $2 \times 10^{3} \mathrm{LD} 50$ s of tetanus neurotoxin, TeNT-Hc and the combined vaccine provided excellent protection; 9 mice vaccinated by TeNT-Hc survived and 1 mouse died from tetanus poisoning. All mice vaccinated by $10 \mu \mathrm{g}$ rSasA $+10 \mu \mathrm{g}$ TeNT-Hc survived without any observed symptoms (Fig. 3B). However, all mice immunized with aluminum hydroxide adjuvant alone did not survive at $24 \mathrm{~h}$ post-challenge. 
A

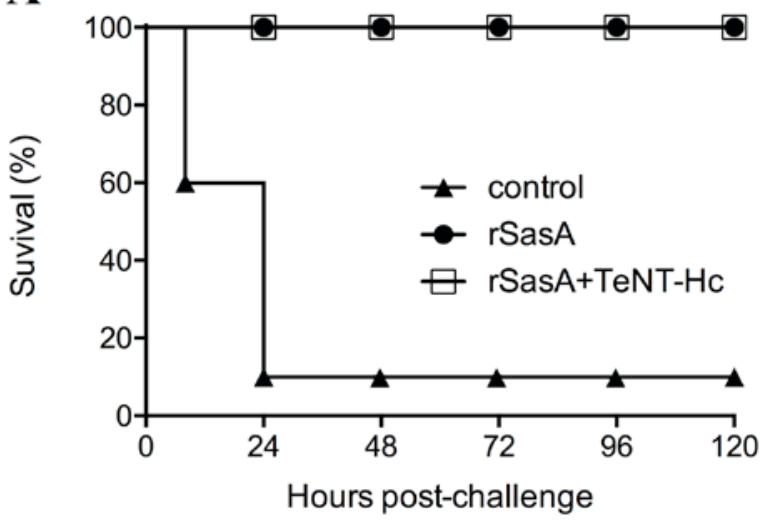

B

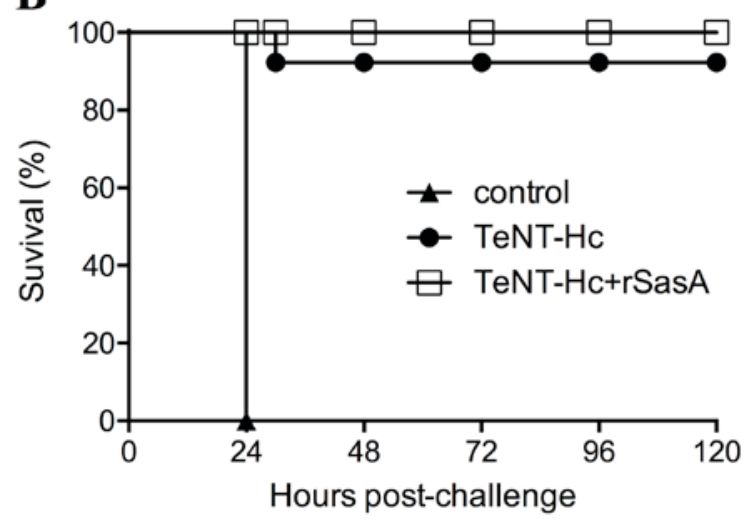

Figure 3. Survival of immunized mice after lethal challenge by $S$. aureus USA300 or TeNT. Groups of 10 female BALB/c (age, 6-8 weeks) mice were immunized three times (at weeks 0,2 and 4) intraperitoneally with $10 \mu \mathrm{g}$ rSasA, $10 \mu \mathrm{g}$ TeNT-Hc, $10 \mu \mathrm{g}$ rSasA+10 $\mu \mathrm{g}$ TeNT-Hc or 0.75 mg aluminum hydroxide adjuvant control. 6 weeks following primary immunization, mice were challenged by intraperitoneal injection with (A) a lethal dose ( $3 \mathrm{x} 10^{9}$ colony-forming units/mouse) of Staphylococcus aureus strain USA300 or (B) by subcutaneous injection with 2x10 ${ }^{3}$ LD50s TeNT. Survival curves were compared using the Gehan-Breslow-Wilcoxon Test. S. aureus, Staphylococcus aureus; TeNT-Hc, C fragment of tetanus neurotoxin; rSasA, recombinant S. aureus surface protein; LD50, the lethal dose that causes mortality in $50 \%$ of subjects.

\section{Discussion}

A combined vaccine may be a reliable and cost-effective strategy to prevent infections caused by two or more pathogens or a single pathogen with various serotypes. Several successful combined vaccines for children have been used for a number of years including, heterologous combinations such as diphtheria-tetanus-pertussis vaccine (19), the combined Hemophilus influenzae type B (HIB), the HIB/hepatitis B (HepB) vaccine (20), the combined HepA-HepB (21), in addition to homologous combinations such as multivalent pneumococcal vaccines (22). The results of the present study suggested that Sas A and TeNT-Hc are promising candidates for a combined vaccine against $S$. aureus and tetanus infections.

Due to antibiotic resistance and a general lack of novel classes of antimicrobial agents against $S$. aureus, vaccines against this pathogen have been extensively investigated. A number of $S$. aureus antigens, including capsular polysaccharide (23), poly-N-acetylglucosamine (24), iron-responsive surface determinant B (25), clumping factor A (26), clumping factor B (27), protein A (28), fibronectin-binding protein (29), collagen adhesion (30), coagulase (31), $\alpha$-hemolysin (32), Panton-Valentine leukocidin (33), staphylococcal enterotoxins (34) and toxic shock syndrome toxin 1 (35) have been studied in animal models. However, no vaccine developed thus far, has demonstrated efficacy in humans (36) for unknown reasons. In the present study, SasA induced a robust specific-antibody reaction and complete protection against the USA300 strain, which is a common source of methicillin-resistant $S$. aureus infections in the USA (37). In addition, SasA is prevalent in $S$. aureus clinical isolates and is immunogenic in humans, as titers of SasA-specific antibodies in the sera of convalescent patients infected by $S$. aureus were higher than that in the sera of healthy people (11). Taken together, SasA is a promising component for a combined vaccine against $S$. aureus. Recombinant TeNT-Hc has exhibited considerable promise as a next-generation subunit vaccine against tetanus $(15,16)$, particularly in formulations that can be administered orally (38) or by intranasal routes (39). Notably, the results of the present study demonstrated no mutual interference between TeNT-Hc and SasA in the antibody response, which is consistent with the fact that recombinant TeNT-Hc has been used as a vaccine carrier to enhance the immunogenicity of conjugate or fusion vaccines (40).

As $S$. aureus consists of a number of virulence factors, the development of a vaccine against this pathogen has proven challenging (41). Therefore, a multi-component vaccine has been suggested to achieve greater protective immunity against $S$. aureus (42). In future studies, more antigens of $S$. aureus may be added the combined vaccine, to determine whether it may confer protection against more clinical $S$. aureus strains and in different animal models.

In conclusion, the present study demonstrated that combined immunization with SasA and TeNT-Hc was as effective as individual immunizations for induction of a serological antibody response. The protective efficacy was not impaired when the antigens were administered in combination. The results provided preliminary evidence for the development of a combined vaccine against $S$. aureus and tetanus infections.

\section{References}

1. Zhang B, Liu Z, Lin Z, Zhang X and Fu W: Microbiologic characteristics of pathogenic bacteria from hospitalized trauma patients who survived Wenchuan earthquake. Eur J Clin Microbiol Infect Dis 31: 2529-2535, 2012.

2. Afshar M, Raju M, Ansell D and Bleck TP: Narrative review: Tetanus-a health threat after natural disasters in developing countries. Ann Intern Med 154: 329-335, 2011.

3. Udo JJ, Anah MU, Ochigbo SO, Etuk IS and Ekanem AD: Neonatal morbidity and mortality in Calabar, Nigeria: A hospital-based study. Niger J Clin Pract 11: 285-289, 2008.

4. Peacock SJ, de Silva I and Lowy FD: What determines nasal carriage of Staphylococcus aureus? Trends Microbiol 9: 605-610, 2001.

5. Lowy FD: Staphylococcus aureus infections. N Engl J Med 339: 520-532, 1998 . 
6. Chalya PL, Mabula JB, Dass RM, Mbelenge N, Mshana SE and Gilyoma JM: Ten-year experiences with Tetanus at a Tertiary hospital in Northwestern Tanzania: A retrospective review of 102 cases. World J Emerg Surg 6: 20, 2011.

7. World Health Organization: Immunization, vaccines and biologicals:Tetanus.http://www.who.int/immunization/diseases/tetanus/en. Accessed November 3, 2016.

8. Skibinski DA, Baudner BC, Singh $\mathrm{M}$ and O'Hagan DT: Combination vaccines. J Glob Infect Dis 3: 63-72, 2011.

9. Yi SQ, Zhang XY, Yang YL, Yang Y, Liu SL, Fu L, Yu CM and Chen W: Immunity induced by Staphylococcus aureus surface protein A was protective against lethal challenge of Staphylococcus aureus in BALB/c mice. Microbiol Immunol 56 : 406-410, 2012

10. Siboo IR, Chambers HF and Sullam PM: Role of SraP, a Serine-Rich Surface Protein of Staphylococcus aureus, in binding to human platelets. Infect Immun 73: 2273-2280, 2005.

11. Roche FM, Massey R, Peacock SJ, Day NP, Visai L, Speziale P Lam A, Pallen M and Foster TJ: Characterization of novel LPXTG-containing proteins of Staphylococcus aureus identified from genome sequences. Microbiology 149: 643-654, 2003

12. Montecucco $\mathrm{C}$ and Schiavo G: Tetanus and botulism neurotoxins: A new group of zinc proteases. Trends Biochem Sci 18: 324-327, 1993.

13. Schiavo G, Benfenati F, Poulain B, Rossetto O, Polverino de Laureto P, DasGupta BR and Montecucco C: Tetanus and botulinum-B neurotoxins block neurotransmitter release by proteolytic cleavage of synaptobrevin. Nature 359: 832-835, 1992.

14. Sinha K, Box M, Lalli G, Schiavo G, Schneider H, Groves M, Siligardi G and Fairweather N: Analysis of mutants of tetanus toxin Hc fragment: Ganglioside binding, cell binding and retrograde axonal transport properties. Mol Microbiol 37: 1041-1051, 2000 .

15. Yu R, Yi S, Yu C, Fang T, Liu S, Yu T, Song X, Fu L, Hou L and $\mathrm{Chen} \mathrm{W}$ : A conformational change of $\mathrm{C}$ fragment of tetanus neurotoxin reduces its ganglioside-binding activity but does not destroy its immunogenicity. Clin Vaccine Immunol 18 $1668-1672,2011$.

16. Yu R, Hou L, Yu C, Liu S, Ren J, Fang T, Zhang X and Chen W: Enhanced expression of soluble recombinant tetanus neurotoxin $\mathrm{Hc}$ in Escherichia coli for use as a tetanus vaccine candidate. Immunobiology 216: 485-490, 2011

17. Rauch S, DeDent AC, Kim HK, Bubeck Wardenburg J, Missiakas DM and Schneewind O: Abscess formation and alpha-hemolysin induced toxicity in a mouse model of Staphylococcus aureus peritoneal infection. Infect Immun 80: 3721-3732, 2012

18. Ulrich R and Miller J: Threshold estimation in two-alternative forced-choice (2AFC) tasks: The Spearman-Kärber method. Percept Psychophys 66: 517-533, 2004.

19. Booy R, Aitken SJ, Taylor S, Tudor-Williams G, Macfarlane JA, Moxon ER, Ashworth LA, Mayon-White RT, Griffiths H and Chapel HM: Immunogenicity of combined diphtheria, tetanus, and pertussis vaccine given at 2, 3 and 4 months versus 3,5 and 9 months of age. Lancet 339: 507-510, 1992.

20. West DJ, Rabalais GP, Watson B, Keyserling HL, Matthews H and Hesley TM: Antibody responses of healthy infants to concurrent administration of a bivalent haemophilus influenzae type b-hepatitis B vaccine with diphtheria-tetanus-pertussis, polio and measles-mumps-rubella vaccines. BioDrugs 15: 413-418, 2001.

21. Joines RW, Blatter M, Abraham B, Xie F, De Clercq N, Baine Y, Reisinger KS, Kuhnen A and Parenti DL: A prospective, randomized, comparative US trial of a combination hepatitis A and B vaccine (Twinrix) with corresponding monovalent vaccines (Havrix and Engerix-B) in adults. Vaccine 19: 4710-4719, 2001.

22. Ortqvist A, Hedlund J, Burman LA, Elbel E, Höfer M, Leinonen M, Lindblad I, Sundelöf B and Kalin M: Randomised trial of 23-valent pneumococcal capsular polysaccharide vaccine in prevention of pneumonia in middle-aged and elderly people. Swedish Pneumococcal Vaccination Study Group. Lancet 351: 399-403, 1998.

23. Robbins JB, Schneerson R, Horwith G, Naso R and Fattom A Staphylococcus aureus types 5 and 8 capsular polysaccharide-protein conjugate vaccines. Am Heart J 147: 593-598, 2004.

24. Maira-Litran T, Kropec A, Goldmann D and Pier GB Biologic properties and vaccine potential of the staphylococcal poly-N-acetyl glucosamine surface polysaccharide. Vaccine 22: $872-879,2004$
25. Joshi A, Pancari G, Cope L, Bowman EP, Cua D, Proctor RA and McNeely T: Immunization with Staphylococcus aureus iron regulated surface determinant B (IsdB) confers protection via Th17/IL17 pathway in a murine sepsis model. Hum Vaccin Immunother 8: 336-346, 2012.

26. Josefsson E, Hartford O, O'Brien L, Patti JM and Foster T: Protection against experimental Staphylococcus aureus arthritis by vaccination with clumping factor $\mathrm{A}$, a novel virulence determinant. J Infect Dis 184: 1572-1580, 2001

27. Schaffer AC, Solinga RM, Cocchiaro J, Portoles M, Kiser KB, Risley A, Randall SM, Valtulina V, Speziale P, Walsh E, et al: Immunization with Staphylococcus aureus clumping factor B, a major determinant in nasal carriage, reduces nasal colonization in a murine model. Infect Immun 74: 2145-2153, 2006.

28. Kim HK, Cheng AG, Kim HY, Missiakas DM and Schneewind O: Nontoxigenic protein A vaccine for methicillin-resistant Staphylococcus aureus infections in mice. J Exp Med 207: $1863-1870,2010$

29. Arrecubieta C, Matsunaga I, Asai T, Naka Y, Deng MC and Lowy FD: Vaccination with clumping factor A and fibronectin binding protein A to prevent Staphylococcus aureus infection of an aortic patch in mice. J Infect Dis 198: 571-575, 2008.

30. Nilsson IM, Patti JM, Bremell T, Höök M and Tarkowski A Vaccination with a recombinant fragment of collagen adhesin provides protection against Staphylococcus aureus-mediated septic death. J Clin Invest 101: 2640-2649, 1998.

31. Cheng AG, McAdow M, Kim HK, Bae T, Missiakas DM and Schneewind O: Contribution of coagulases towards Staphylococcus aureus disease and protective immunity. PLoS Pathog 6: e1001036, 2010.

32. Bubeck Wardenburg J and Schneewind O: Vaccine protection against Staphylococcus aureus pneumonia. J Exp Med 205: 287-294, 2008.

33. Brown EL, Dumitrescu O, Thomas D, Badiou C, Koers EM, Choudhury P, Vazquez V, Etienne J, Lina G, Vandenesch F and Bowden MG: The Panton-Valentine leukocidin vaccine protects mice against lung and skin infections caused by Staphylococcus aureus USA300. Clin Microbiol Infect 15: 156-164, 2009.

34. Hu DL, Omoe K, Narita K, Cui JC, Shinagawa K and Nakane A: Intranasal vaccination with a double mutant of staphylococcal enterotoxin C provides protection against Staphylococcus aureus infection. Microbes Infect 8: 2841-2848, 2006.

35. Hu DL, Omoe K, Sasaki S, Sashinami H, Sakuraba H, Yokomizo Y, Shinagawa K and Nakane A: Vaccination with nontoxic mutant toxic shock syndrome toxin 1 protects against Staphylococcus aureus infection. J Infect Dis 188: 743-752, 2003.

36. Bagnoli F, Bertholet S and Grandi G: Inferring reasons for the failure of Staphylococcus aureus vaccines in clinical trials. Front Cell Infect Microbiol 2: 16, 2012.

37. Diep BA, Gill SR, Chang RF, Phan TH, Chen JH, Davidson MG, Lin F, Lin J, Carleton HA, Mongodin EF, et al: Complete genome sequence of USA300, an epidemic clone of community-acquired meticillin-resistant Staphylococcus aureus. Lancet 367: 731-739, 2006.

38. Tacket CO, Galen J, Sztein MB, Losonsky G, Wyant TL, Nataro J, Wasserman SS, Edelman R, Chatfield S, Dougan G and Levine MM: Safety and immune responses to attenuated Salmonella enterica serovar typhi oral live vector vaccines expressing tetanus toxin fragment C. Clin Immunol 97: 146-153, 2000.

39. Lee S, Belitsky BR, Brown DW, Brinker JP, Kerstein KO, Herrmann JE, Keusch GT, Sonenshein AL and Tzipori S: Efficacy, heat stability and safety of intranasally administered Bacillus subtilis spore or vegetative cell vaccines expressing tetanus toxin fragment C. Vaccine 28: 6658-6665, 2010.

40. Bongat AF, Saksena R, Adamo R, Fujimoto Y, Shiokawa Z, Peterson DC, Fukase K, Vann WF and Kovác P: Multimeric bivalent immunogens from recombinant tetanus toxin $\mathrm{HC}$ fragment, synthetic hexasaccharides, and a glycopeptide adjuvant. Glycoconj J 27: 69-77, 2010.

41. Salgado-Pabón W and Schlievert PM: Models matter: The search for an effective Staphylococcus aureus vaccine. Nat Rev Microbiol 12: 585-591, 2014.

42. Stranger-Jones YK, Bae T and Schneewind O: Vaccine assembly from surface proteins of Staphylococcus aureus. Proc Natl Acad Sci USA 103: 16942-16947, 2006. 